\title{
HIGH SENSITIVITY C-REACTIVE PROTEIN IN CHRONIC OBSTRUCTIVE PULMONARY DISEASE AND ASTHMA- A PROSPECTIVE STUDY IN NORTH INDIA
}

\author{
Vinod Kumar1, Achint Singh², Ritu Bhagat ${ }^{3}$, Roopali Jandyal ${ }^{4}$
}

${ }^{1}$ Assistant Professor, Department of Medicine, GMC, Doda, Jammu and Kashmir, India.

${ }^{2}$ Senior Resident, Department of Medicine, GMC, Doda, Jammu and Kashmir, India.

3 Senior Resident, Department of Pathology, GMC, Doda, Jammu and Kashmir, India.

${ }_{4}^{4}$ Senior Resident, Department of Pathology, GMC, Doda, Jammu and Kashmir, India.

\section{ABSTRACT}

\section{BACKGROUND}

High sensitivity C-reactive protein (hs-CRP) is an acute phase reactant with well documented sensitivity that is commonly used to diagnose infections and inflammatory conditions like COPD and Asthma. We wanted to study the plasma hs-CRP levels in patients of COPD and asthma.

\section{METHODS}

This is a prospective study conducted for a period of one year from Nov. 2017- Oct. 2018, conducted at GMC, Jammu, which is a tertiary care centre. In our study, out of 100 patients who were studied, 50 were male (50\%) and 50 were female (50\%) with male: female ratio of 1:1.

\section{RESULTS}

Thirty (30\%) patients were asthmatics and seventy (70\%) patients had COPD, with asthma to COPD ratio of 1:2.3.

\section{CONCLUSIONS}

High sensitivity C-reactive protein (CRP), which is an inflammatory marker, in the present study had a strong association with COPD and asthma both in males and females with interaction p-values in case of male asthmatics (0.003), female asthmatics (0.01), COPD males (0.001) and COPD females (0.001).

HOW TO CITE THIS ARTICLE: Kumar V, Singh A Bhagat R, et al. High sensitivity C-reactive protein in chronic obstructive pulmonary disease and asthma- a prospective study in North India. J. Evolution Med. Dent. Sci. 2019;8(18):1494-1497, DOI: $10.14260 /$ jemds/2019/332

\section{BACKGROUND}

COPD is a leading and increasing cause of morbidity and mortality worldwide ${ }^{1}$ and at present over 600 million people worldwide have COPD, the morbidity and mortality continue to escalate at an alarming rate. Asthma is a chronic condition involving the respiratory system in which the airways occasionally constrict, become inflamed and are lined with excessive amounts of mucous, often in response to one or more triggers. Although asthma is more common in affluent countries, it is by no means a problem restricted to affluent only. WHO estimates that there are between 15 and 20 million asthmatics in India. Globally, asthma is responsible for around 180, 000 deaths annually. High sensitivity Creactive protein (hs-CRP) is an acute phase reactant with well documented sensitivity that is commonly used to diagnose infections and inflammatory conditions like COPD and asthma. $^{2}$ Recent population based studies showed associations of increased levels of serum hs-CRP with a high frequency of airway hyper-responsiveness and low forced expiratory volume in one second $\left(\mathrm{FEV}_{1}\right)$ among subjects without heart disease suggesting that systemic inflammation may be associated with respiratory impairment. ${ }^{3}$

'Financial or Other Competing Interest': None.

Submission 09-03-2019, Peer Review 19-04-2019,

Acceptance 26-04-2019, Published 06-05-2019.

Corresponding Author:

Dr. Ritu Bhagat,

D/o. K. C. Bhagat

209, Colonel Colony,

Talab Eillo-Bohri, Jammu-180001,

Jammu and Kashmir, India.

E-mail: ritubhagat8600@gmail.com

DOI: $10.14260 /$ jemds $/ 2019 / 332$

\section{METHODS}

This prospective study entitled High Sensitivity C-Reactive Protein in COPD and Asthma was carried out in the GMC, Jammu for a period of one-year w.e.f. Nov. 2017 to Oct. 2018. A detailed history, complete physical, clinical, systemic examination and lab investigations were done. Immunoturbidimetric method was employed for quantitative determination of hs-CRP.

\section{Inclusion Criteria}

All patients who had history along with clinical signs and symptoms with the complaint of chronic productive cough, breathlessness with seasonal variability and with history of smoking and occupational smoke and dust exposure suggestive of COPD and Asthma and confirmed by spirometry were included.

\section{Exclusion Criteria}

1. Diabetes mellitus.

2. Chronic inflammatory diseases like rheumatoid arthritis, SLE.

3. Atherosclerosis associated heart disease.

4. Pulmonary Kochs.

5. Interstitial lung disease.

6. Pneumothorax.

7. Pleural effusion.

\section{RESULTS}

The present study was carried out on 100 patients of COPD and Bronchial Asthma. The objective of this study was to study the plasma hs-CRP levels in these patients in Government Medical College Hospital, Jammu so as to 
correlate the values of plasma hs-CRP levels with degree of severity of COPD and asthma.

\begin{tabular}{|c|c|c|c|c|}
\hline \multirow[b]{2}{*}{$\begin{array}{c}\text { Age } \\
\text { (in Years) }\end{array}$} & \multicolumn{2}{|c|}{ Asthmatic } & \multicolumn{2}{|c|}{ COPD } \\
\hline & $\begin{array}{c}\text { Males } \\
(n=13) \\
\text { No. }(\%)\end{array}$ & $\begin{array}{c}\text { Females } \\
(n=17) \\
\text { No. }(\%)\end{array}$ & $\begin{array}{c}\text { Males } \\
(n=37) \\
\text { No. }(\%)\end{array}$ & $\begin{array}{c}\text { Females } \\
(n=33) \\
\text { No. }(\%)\end{array}$ \\
\hline $20-29$ & $6(46.15)$ & $6(35.29)$ & - & - \\
\hline $30-39$ & $6(46.15)$ & $11(64.70)$ & - & - \\
\hline $40-49$ & $1(7.69)$ & - & $1(2.7)$ & $2(6.06)$ \\
\hline $50-59$ & - & - & $6(16.21)$ & $5(15.15)$ \\
\hline $60-69$ & - & - & $20(54.05)$ & $25(75.75)$ \\
\hline $70-79$ & - & - & $10(27.02)$ & $1(3.03)$ \\
\hline Total & $13(100)$ & $17(100)$ & $37(100)$ & $33(100)$ \\
\hline & & tients & & \\
\hline
\end{tabular}

\begin{tabular}{|c|c|c|}
\hline Presentation & No. of Patients & Percentage (\%) \\
\hline Asthma & 30 & 30 \\
\hline COPD & 70 & 70 \\
\hline
\end{tabular}

Table 2. Distribution of Patients According to Presentation

\begin{tabular}{|c|c|c|c|c|c|c|}
\hline \multirow[b]{2}{*}{ Variables } & \multicolumn{2}{|c|}{ Asthmatic } & \multicolumn{2}{|c|}{ COPD } & \multicolumn{2}{|c|}{ Healthy } \\
\hline & $\begin{array}{c}\text { Males } \\
(\mathrm{n}=13)\end{array}$ & \begin{tabular}{|l|} 
Females \\
$(\mathrm{n}=17)$
\end{tabular} & $\begin{array}{l}\text { Males } \\
(n=37)\end{array}$ & $\begin{array}{l}\text { Females } \\
(\mathrm{n}=33)\end{array}$ & \begin{tabular}{|c|} 
Males \\
$(n=10)$
\end{tabular} & $\begin{array}{c}\text { Females } \\
(n-10)\end{array}$ \\
\hline $\begin{array}{c}\text { Age in } \\
\text { years } \\
(\text { Mean } \pm \\
1 \mathrm{SD})\end{array}$ & $\begin{array}{c}31.37 \pm \\
6.64\end{array}$ & $\begin{array}{c}31.67 \pm \\
5.63\end{array}$ & $\begin{array}{r}65.48 \\
\pm 7.55\end{array}$ & $\begin{array}{c}61.93 \pm \\
6.18\end{array}$ & $\begin{array}{c}52.23 \pm \\
14.58\end{array}$ & $\begin{array}{c}43.33 \pm \\
10.64\end{array}$ \\
\hline $\begin{array}{c}\text { Height in } \\
\text { meters } \\
(\text { Mean } \pm \\
1 \mathrm{SD}) \\
\end{array}$ & $\begin{array}{c}1.61 \pm \\
0.09\end{array}$ & $\begin{array}{c}1.54 \pm \\
0.04\end{array}$ & $\begin{array}{c}1.68 \pm \\
0.04\end{array}$ & $\begin{array}{l}1.53 \pm \\
0.043\end{array}$ & $\begin{array}{c}1.65 \pm \\
0.61\end{array}$ & $\begin{array}{c}1.52 \pm \\
0.13\end{array}$ \\
\hline $\begin{array}{c}\text { Weight in } \\
\text { Kgs } \\
(\text { Mean } \pm \\
1 \text { SD) }\end{array}$ & $\begin{array}{l}54 \pm \\
4.44\end{array}$ & $\begin{array}{c}50.38 \pm \\
4.05\end{array}$ & $\begin{array}{l}60 \pm \\
7.44\end{array}$ & $\begin{array}{c}44.69 \pm \\
4.78\end{array}$ & $\begin{array}{c}59.94 \pm \\
4.50\end{array}$ & $\begin{array}{c}46.16 \pm \\
5.24\end{array}$ \\
\hline$T$ & J" & 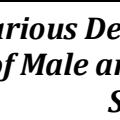 & $g r$ & 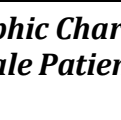 & c & 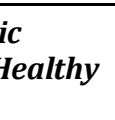 \\
\hline
\end{tabular}

\begin{tabular}{|c|c|c|c|c|c|c|}
\hline Variables & \multicolumn{3}{|c|}{ PEFR\% Predicted } & \multicolumn{3}{c|}{ hs-CRP Values (mg/L) } \\
\cline { 2 - 7 } & $\begin{array}{c}\text { Mini- } \\
\text { mum }\end{array}$ & $\begin{array}{c}\text { Maxi- } \\
\text { mum }\end{array}$ & $\begin{array}{c}\text { Mean } \\
\pm \text { 1 SD }\end{array}$ & $\begin{array}{c}\text { Mini- } \\
\text { mum }\end{array}$ & $\begin{array}{c}\text { Maxi- } \\
\text { mum }\end{array}$ & $\begin{array}{c}\text { Mean } \pm \\
\text { 1 SD }\end{array}$ \\
\hline $\begin{array}{c}\text { Males } \\
(\mathrm{n}=13)\end{array}$ & 58 & 64 & $62 \pm 3$ & 3.76 & 21.72 & $\begin{array}{c}9.84 \pm \\
2.80\end{array}$ \\
\hline $\begin{array}{c}\text { Females } \\
(\mathrm{n}=17)\end{array}$ & 49 & 77 & $\begin{array}{c}61 \pm \\
6.36\end{array}$ & 3.76 & 19.86 & $\begin{array}{c}8.25 \pm \\
3.16\end{array}$ \\
\hline \multicolumn{6}{|c|}{ Table 4. Asthmatic Patients (Male and Female) } \\
\hline
\end{tabular}

\begin{tabular}{|c|c|c|c|}
\hline Variables & Minimum & Maximum & Mean \pm 1 SD \\
\hline $\begin{array}{c}\text { Duration of smoking } \\
\text { (in years) }\end{array}$ & 25 & 60 & $41.56 \pm 7.64$ \\
\hline FEV 1 (\% Predicted) $^{\text {F }}$ & 30 & 68 & $51 \pm 8.14$ \\
\hline FVC (\% Predicted) & 57 & 83 & $71 \pm 6.54$ \\
\hline $\begin{array}{c}\text { FEV } 1 \text { FVC (\% } \\
\text { Predicted) }\end{array}$ & 50 & 90 & $71 \pm 11.06$ \\
\hline hs-CRP (mg/L) & 3.80 & 21.72 & $9.13 \pm 4.02$ \\
\hline \multicolumn{4}{|c|}{ Table 5. COPD Males (n=37) } \\
\hline
\end{tabular}

\begin{tabular}{|c|c|c|c|}
\hline Variables & Minimum & Maximum & Mean \pm 1 SD \\
\hline $\begin{array}{c}\text { Duration of smoking } \\
\text { (in years) }\end{array}$ & 25 & 50 & $40 \pm 5.22$ \\
\hline $\begin{array}{c}\text { FEV } 1 \\
\text { (\% Predicted) }\end{array}$ & 33 & 85 & $44.48 \pm 10.06$ \\
\hline $\begin{array}{c}\text { FVC } \\
\text { (\% Predicted) }\end{array}$ & 52 & 102 & $74.40 \pm 12.93$ \\
\hline $\begin{array}{c}\text { FEV } 1 / \text { FVC } \\
\text { \% Predicted) }\end{array}$ & 43 & 73 & $58.30 \pm 12.22$ \\
\hline hs-CRP (mg/L) & 3.70 & 17 & $9.60 \pm 3.73$ \\
\hline \multicolumn{4}{|c|}{ Table 6. COPD Females (n= 33) } \\
\hline
\end{tabular}

\section{DISCUSSION}

This study was done on 100 patients who presented to Government Medical College Hospital, Jammu with the history of smoking, occupational exposure and family history of asthma. Seventy out of 100 patients were COPD and 30 were asthmatics. The objective of this study was to find out the plasma hs-CRP levels in patients of asthma and COPD and to correlate the values of hs-CRP levels with degree of severity of asthma and COPD.

In our study, out of 100 patients who were studied, 50 were male $(50 \%)$ and 50 were females $(50 \%)$ with ratio of male: female was $1: 1$. Thirty (30\%) patients were asthmatics and $70(70 \%)$ patients had COPD, with asthma to COPD ratio of 1: 2.3. In case of asthma, there were 13 male and 17 female patients with a male: female ratio of $0.76: 1$, whereas in case of COPD, there were 37 males and 33 females with male: female ratio of 1.12: 1 . Maximum number of male and female patients (i.e. $20 \%$ and $25 \%$ respectively) were in the age group of 60-69 years. Male: Female ratio in our study in case of COPD was 1.2: 1, whereas in the studies by PintoPlata et $\mathrm{al}^{4}$ and Dahl ${ }^{5}$ was 1.43: 1 and 1.26: 1, respectively. $66 \%$ of the patients were female in the study of Takemura et al (2006), 6 whereas the percentage of female patients in the study by Dahl $(2006)^{5}$ was $40 \%$. In the studies by Stolz et $\mathrm{al}^{7}$ and Higashimoto et $a \mathrm{l}, 8$ the percentage of female patients was $55 \%$ and $42 \%$, respectively.

In our study, the mean age of patients in case of asthma was 31.37 years in males and 33.07 years in females, whereas it was 65.48 years in COPD males and 61.93 years in COPD females. On the other hand, mean age in case of controls i.e. healthy male and female subjects was 43.43 years. Whereas the average age in case of various studies by Olafsdottir et al, 9 Takemura et al ${ }^{6}$ was 41.6 years and $48 \pm 21$ years, respectively in case of asthma, while in case of COPD, the average age in different studies by Broekhuizen et al, ${ }^{10}$ PintoPlata et $\mathrm{al}^{4}$ and Stolz et al ${ }^{7}$ was 46 years, 63 years, 66 years and 70 years, respectively. Smoking is a well-known risk factor associated with COPD. In our study, $100 \%$ of the patients with COPD were smokers. Similarly, 100\% patients in the study by Takemura et $\mathrm{al}^{6}$ were smokers. None of the patients in asthma group were smokers in our study. On the contrary, in a study by Olafsdottir et al $^{9}$ about $27.8 \%$ patients were smokers.

In our study, the BMI in case of male asthmatics, female asthmatics, COPD males and COPD females was 20.84, 21.25, 21.27 and $20.08 \mathrm{~kg} / \mathrm{m}^{2}$, respectively, whereas in a study by Olafsdottir et al $^{9}$ it was 25.04 and $26.01 \mathrm{~kg} / \mathrm{m}$ in case of male asthmatics and female asthmatics, respectively. Takemura et $\mathrm{al}^{6}$ reported $22 \pm 3$ and $23 \pm 4 \mathrm{~kg} / \mathrm{m}$ BMI in male and female asthmatics in their study. 
In case of COPD, Pinto-Plata et $\mathrm{al}^{4}$ reported 27.04 and $26.54 \mathrm{~kg} / \mathrm{m}$ BMI in males and females, respectively. Mean PEFR\% predicted in case of asthmatic males and females was $72 \%$ each in a study by Takemura et al, 6 whereas in our study it was $62 \pm 3 \%$ and $61 \pm 6.36 \%$ in case of male and female asthmatic patients, respectively.

In a study by Stolz et al, 7 percentage of patients with mild, moderate, severe and very severe asthma was 8.4, 22.2, 45.5 and $24 \%$, respectively, whereas in our study the percentage of mild, moderate, severe and very severe patients was 29.72 , $32.43,24.32$ and $13.51 \%$, respectively in case of males and $25,33.3,21.87$ and $21.87 \%$, respectively in case of females.

In our study, mean hs-CRP value in case of male asthmatics was $9.84 \pm 2.80 \mathrm{mg} / \mathrm{L}$. In mild, moderate and severe disease, it was $6.84 \pm 1.66,9.68 \pm 2.78$ and $15.84 \pm$ $4.12 \mathrm{mg} / \mathrm{L}$, respectively. In asthmatic females, the mean hs$\mathrm{CRP}$ value was $8.25 \pm 3.16 \mathrm{mg} / \mathrm{L}$, and it went on increasing with severity of disease i.e. in mild, moderate and severe disease, it was $4.92 \pm 1.12,7.86 \pm 2.32$ and $13.90 \pm 3.84 \mathrm{mg} / \mathrm{L}$, respectively.

In case of COPD males, the mean hs-CRP value was $9.13 \pm$ $4.02 \mathrm{mg} / \mathrm{L}$ and its valued varied with increasing severity i.e. in mild, moderate, severe and very severe disease, it was 4.80 $\pm 1.2,6.72 \pm 2.6,10.84 \pm 4.8$ and $15.68 \pm 6.8 \mathrm{mg} / \mathrm{L}$, respectively.

In case of COPD females, the mean value of hs-CRP was $9.60 \pm 3.73 \mathrm{mg} / \mathrm{L}$, whereas in case of mild, moderate, severe and very severe disease, it was $4.32 \pm 1.08,6.92 \pm 2.4,10.36 \pm$ 3.24 and $15.84 \pm 4.82 \mathrm{mg} / \mathrm{L}$, respectively.

In other studies by Qian et al,11 the values of hs-CRP were $0.23-0.51 \mathrm{mg} / \mathrm{L}, 0.51-1.42 \mathrm{mg} / \mathrm{L}$ and > $1.42 \mathrm{mg} / \mathrm{L}$ in mild, moderate and severe asthma, respectively, whereas in a study by Soferman et al,12 the mean values of hs-CRP in severe asthma were $14.28 \pm 8.45 \mathrm{mg} / \mathrm{L}$.

In another study by Panaszek et al,13 the serum concentrations of hs-CRP ranged from 0.20 to $14.5 \mathrm{mg} / \mathrm{L}$ in both male and female asthmatic patients. The values of serum hs-CRP concentration ranged from $12.9 \mathrm{mg} / \mathrm{L}$ to $50.6 \mathrm{mg} / \mathrm{L}$ in male and female COPD patients (mild to very severe disease) in a study by Stolz et al.7 In a study by Pinto-Plata et al, ${ }^{4}$ the serum concentrations of hs-CRP in both male as well as female patients was reported to be between 3.7 to $6.3 \mathrm{mg} / \mathrm{L}$.

The value of serum hs-CRP ranged from 3.33 to 12.85 $\mathrm{mg} / \mathrm{L}$ in male and female asthmatic patients in a study by Broekhuizen et al. ${ }^{10}$ It ranged from 2.9 to $13.7 \mathrm{mg} / \mathrm{L}$ in COPD male and female patients in a study by Schneider et al.14

High sensitivity C-reactive protein (hs-CRP), which is an inflammatory marker, in the present study had a strong association with COPD and asthma both in males and females with interaction p-values in case of male asthmatics (0.003), female asthmatics (0.01), COPD males (0.001) and COPD females (0.001).

Above observations of our study are generally in confirmation of the results by studies conducted by Broekhuizen et al,10 Olafsdottir et al, ${ }^{9}$ Pinto-Plata et al, ${ }^{4}$ Schneider et al,14 Takemura et al,6 Panaszek et al,13 Qian et al ${ }^{11}$ and Soferman et al $^{13}$ with the value of hs-CRP being directly proportional to the severity of disease both in asthma and COPD.

\section{CONCLUSIONS}

As hs-CRP reflects chronic inflammation of respiratory tract, it correlates with severity of COPD and Bronchial Asthma, in which the pathology is same. It, therefore, is an important biomarker of severity of disease. In addition, if follow-up studies are done, hs-CRP may also be predictor of morbidity and mortality of the above-mentioned entities, thereby helping in the modulation of the treatment of the conditions. Many anti-inflammatory drugs can then be tried for experimental purpose to decelerate the progress of chronic inflammatory disease. Atorvastatin is a potent antiinflammatory drug used in treating various antiinflammatory diseases like rheumatoid arthritis. Its use in COPD and asthma can be contemplated.

\section{REFERENCES}

[1] Pauwels R, Buist A, Calverley PM, el al. Global strategy for the diagnosis, management and prevention of chronic obstructive pulmonary disease. Am J Respir Crit Care Med 2001;163(5):1256-76.

[2] Malo O, Sauleda J, Busquets X, et al. Systemic inflammation during exacerbations of chronic obstructive pulmonary disease. Arch Bronconeumol 2002;38(4):172-6.

[3] Kony S, Zureik M, Driss F, et al. Association of bronchial hyper-responsiveness and lung function with $\mathrm{C}$ - reactive protein (CRP): a population based study. Thorax 2004;59(10):892-6.

[4] Pinto-Plata VM, Mullerova H, Toso JF, et al. C-reactive protein in patients with COPD, control smokers and non-smokers. Thorax 2006;61(1):23-8.

[5] Dahl M, Vestbo J, Lange P, et al. C-reactive protein as a predictor of prognosis in chronic obstructive pulmonary disease. Am J Resp Crit Care Med 2007;175(3):250-5.

[6] Takemura M, Matsumoto $H$, Niimi A, et al. High sensitivity C-reactive protein in asthma. Eur Respir J 2006;27(5):908-12.

[7] Stolz D, Christ-Crain M, Morgenthaler NG, et al. Copeptin, C-reactive protein and procalcitonin as prognostic biomarkers in acute exacerbation of COPD. Chest 2007;131(4):1058-67.

[8] Higashimoto Y, Yamagata Y, Taya S, et al. Systemic inflammation in COPD and asthma: similarities and differences. Nihon Kokyuki Gakkai Zasshi 2008;46(6):443-7.

[9] Olafsdottir IS, Gislason T, Thjodleifsson B, et al. Creactive protein levels are increased in non-allergic but not allergic asthma: a multicentre epidemiological study. Thorax 2005;60(6):451-4.

[10] Broekhuizen R, Wouters EFM, Creutzberg EC, et al. Raised CRP levels mark metabolic and functional impairment in advanced COPD. Thorax 2006;61(1):17-22.

[11] Qian FH, Zhang Q, Zhou LF, et al. High-sensitivity Creactive protein: a predicative marker in severe asthma. Respirology 2008;13(5):664-9.

[12] Soferman R, Glatstein M, Sivan Y, et al. HsCRP levels: measurement of airway inflammation in asthmatic children. Pediatr Int 2008;50(1):12-6. 


\section{Jemds.com}

[13] Panaszek B, Liebhart E, Liebhart J, et al. Serum concentration of C-reactive protein is not a good marker of bronchial hyper-responsiveness. Arch Immunol Ther Exp (Warsz) 2007;55(5):341-5.

\section{Original Research Article}

[14] Schneider A, Dinant GJ, Maag I, et al. The added value of C-reactive protein to clinical signs and symptoms in patients with obstructive airway disease: results of a diagnostic study in primary care. BMC Fam Pract 2006;7:28. 